\title{
Technology for biohumus production, an alternative to conventional fertilizers for bio agriculture
}

\author{
Evelin-Anda Laza $^{1 *}$, Oana Cristea, ${ }^{1}$ Nicoleta Ungureanu $^{2}$ \\ ${ }^{1}$ National Institute of Research - Development for Machines and Installations designed to Agriculture \\ and Food Industry - INMA, Bucharest 013813, Romania \\ ${ }^{2}$ Polytechnic University of Bucharest, Faculty of Biotechnical Systems Engineering, Bucharest
}

\begin{abstract}
Composting is the process of decomposition and transformation of solid organic substances by microorganisms (mainly bacteria and fungi) into a stable material, which can be used (depending on characteristics) in agriculture, instead of chemical fertilizers or land improvement works (soil improvement. The composting process consists of two stages: mechanical treatment and decomposition (fermentation). In the case of mechanical treatment, the waste is crushed, homogenized and prepared for biological treatment, fermentation. The fermentation stage consists in three main stages, namely the mesophilic fermentation stage, the thermophilic fermentation stage and the maturation stage of the compost.
\end{abstract}

\section{Introduction}

This paper aims to bring to the attention of farmers the benefits of reusing animal and agricultural waste through composting. Composting is the process of decomposition and transformation of solid organic substances by microorganisms (mainly bacteria and fungi) into a stable material, which can be used (depending on characteristics) in agriculture, instead of chemical fertilizers or land improvement works (soil improvement) $[1,2]$.

Compost is the best mulch and natural soil amendment and it can be used instead of commercial fertilizers. But the most important thing is that it is a cheap product. The use of compost leads to improved soil structure, improved excessive textures, improved aeration and increased water storage capacity, increased soil fertility and stimulated the development of a healthy root system of plants. Organic matter applied through the compost is like food for microorganisms in the soil[1,2] .

Composting can be done in households, in open piles, in special plastic compost bins or in other containers. In the case of farms and composting stations, composting can be done on specially designed platforms, the material for composting being arranged in long rows (furrows) and turned periodically (using special furrow reshaping equipment), in systems of aerated static piles using perforated pipes or in special containers. Good composting consists in ensuring adequate environmental conditions for microbial life. Organisms responsible for composting need three elements to live $[2,3,4]$ :

\footnotetext{
*Corresponding author: eveline_anda@yahoo.com
} 
- Food for microorganisms, composed of a mixture of carbon-rich ingredients (brownhard-dry, such as straw, tree branches, sawdust) and nitrogen-rich ingredients (soft-greenmoist such as weeds, leaves, residues of fruits and vegetables). It is important that both dry and green waste be used in the composting process to obtain a high quality compost $[4,5,6]$.

- Humidity, especially present in nitrogenous ingredients, or from water added separately; the humidity ensures an environment favorable for the multiplication of aerobic bacteria and accelerates the composting process $[4,5,6]$.

- Air, whose circulation is favored by hard carbonate ingredients. The microbes involved in the composting process are aerobic, they need air to grow and decompose waste. In the absence of proper aeration of the mixture, rotten compost is formed (anaerobic), a low quality organic fertilizer and dangerous for the environment. It generates unpleasant odors and methane gas, while the leachate resulting from rot drains into the soil and later reaches the groundwater $[4,5,6]$.

\section{Methodology}

A suitable location was found for the production of compost (platform for its production. The organic materials were stored on the composting platform so that they could be transformed into compost. They were carried out regular inspections of temperature and humidity and to prevent dispersal of the waste and the penetration of rodents and insects. A compost aerator was used to aerate the compost. In order to speed up the composting process of the plant residues that were to be used, they were chopped as small as possible. On the platform for composting was added a first layer of resulting waste from trimming trees or other plant debris will be obtained until the film thickness of residues $10-15 \mathrm{~cm}$. This is actually a base layer for the rest of the waste added later in the composting process.

To activate the composting process, soil and manure was added. Once the "bed" of garden waste was finished, the addition of vegetable waste and and other garden waste began.

As main operational stages in the production of compost we list: humidity regulation in hot periods twice a week, aeration at least once a week, the compost that went through the thermophilic phase was covered with foil. The prisms were covered again when lower temperatures were recorded in order to better maintain the temperature overnight (higher thermal inertia), the parameters were monitored once every 2 weeks (internal) and general outsourced analyzes 1 time per month and the activity of bacteria / fungi / insects present in the compost was monitored. A cylindrical sieve was used to sort the resulting compost.

The determination of the macroelements, microelements and other elements necessary for the good development of the plants in the obtained compost was performed with the help of the Elemental Analysis Kits. Compost samples subjected to chemical analysis were taken from the composting platform.

Figure 1 shows a mobile compost kit for on-site analysis and figure 2 shows a thermometer for measuring the temperature of the compost 


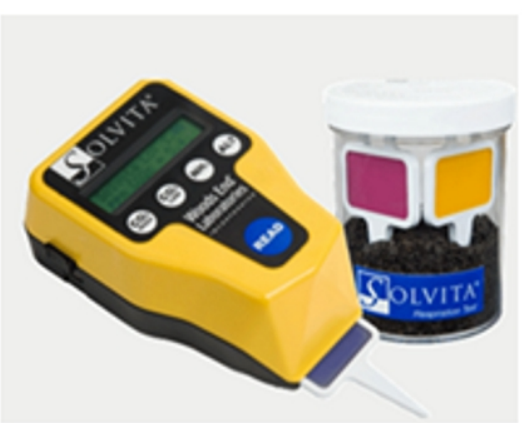

Fig.1. Mobile compost test kit

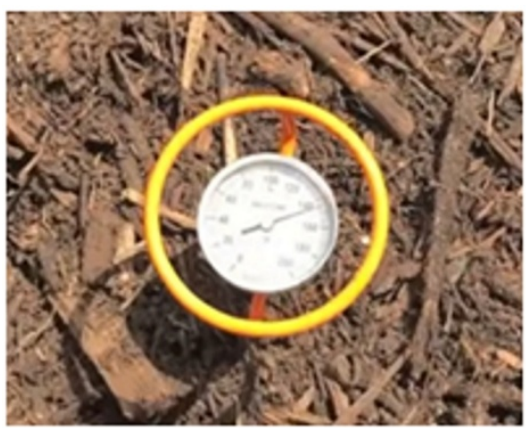

Fig. 2 Thermometer

When making the composting recipe, the specialized information on the carbon / nitrogen ratio in table 1 was taken into account.

Table 1 Materials rich in Nitrogen and carbon

\begin{tabular}{|l|c|l|c|}
\hline \multicolumn{1}{|c|}{ Type of waste } & \multicolumn{1}{c|}{ C / N ratio } & \multicolumn{1}{c|}{ Type of waste } & C / N ratio \\
\hline \multicolumn{2}{|c|}{ Waste rich in Nitrogen } & \multicolumn{2}{c|}{ Waste rich in Carbon } \\
\hline Liquid manure & $2-3$ & Fruit leftovers & 34 \\
\hline Solid manure & 10 & Leaves & $50-65$ \\
\hline Cut grass & $12-15$ & Straw, oats & $50-63$ \\
\hline Vegetable waste & 13 & Tree bark & $110-140$ \\
\hline Kitchen waste & 23 & $\begin{array}{l}\text { Remains from bush } \\
\text { cleaning }\end{array}$ & $110-160$ \\
\hline Potato plant & 25 & Sawdust & $120-510$ \\
\hline Horse manure & 25 & Paper / cardboard & $220-520$ \\
\hline
\end{tabular}

With the help of this information we adjusted the $\mathrm{C} / \mathrm{N}$ ratio of the material introduced in to the pile.

The process of decomposition depends on several factors. These factors and the relationships between them, influence the speed of the decomposition process, the decomposition phase and the activity of microorganisms.

The type of substrate, by using a certain material or a mixture of different materials, many properties of the process can be influenced, such as: the volume of interstices, humidity, or particle size of the material introduced in the pile, but also the quality of the compost. Therefore, the mixture of introduced materials (the substrate used) is the most important step in producing a quality compost.

Temperature is a value for determining the degree of putrefaction.

Humidity, the microorganisms need water to survive and a constant humidity is required to ensure the continuation of the decomposition process.

$p H$ level: The $\mathrm{pH}$ values must be betwen 7 and 11 .

$C / N$ ratio:. The optimum carbon : nitrogen ratio should be between 20: 1 and 35: 1

Figure 3 shows the materials used to prepare the compost, and figure 4 shows Images during the experimentation of the recipe for composting 

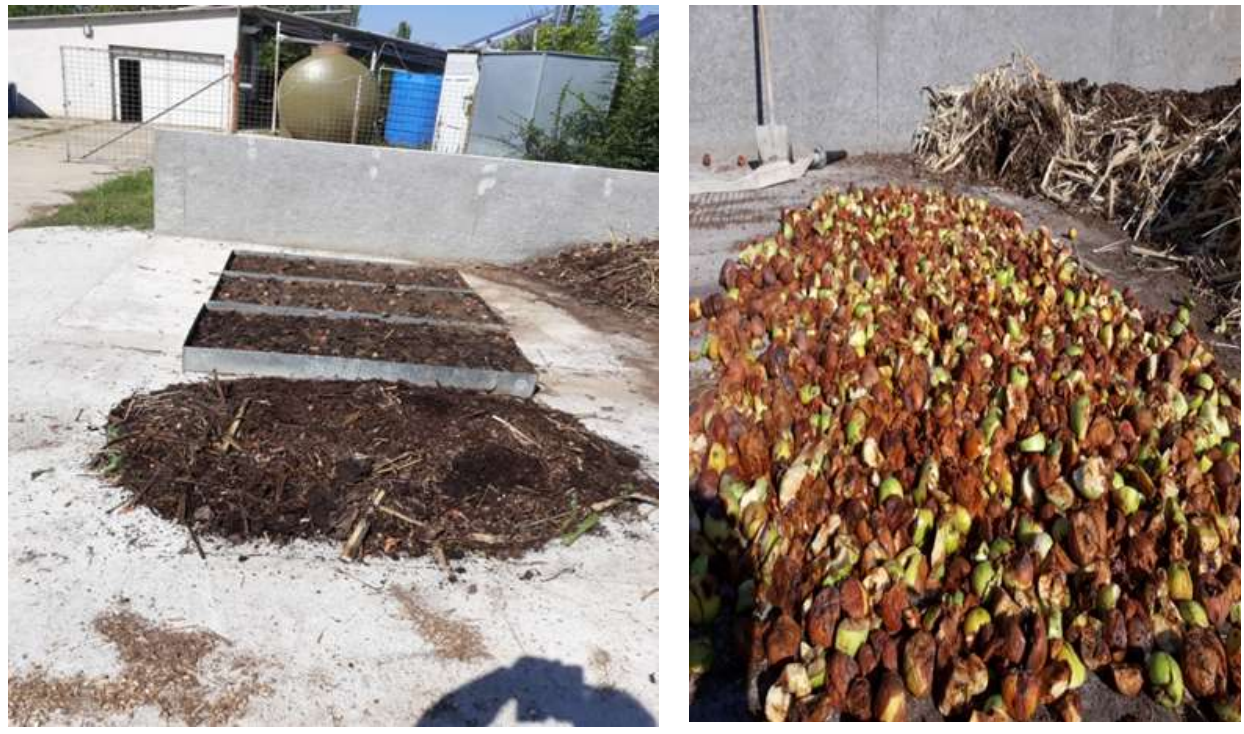

Fig.3 Materials used to prepare the recipe for composting
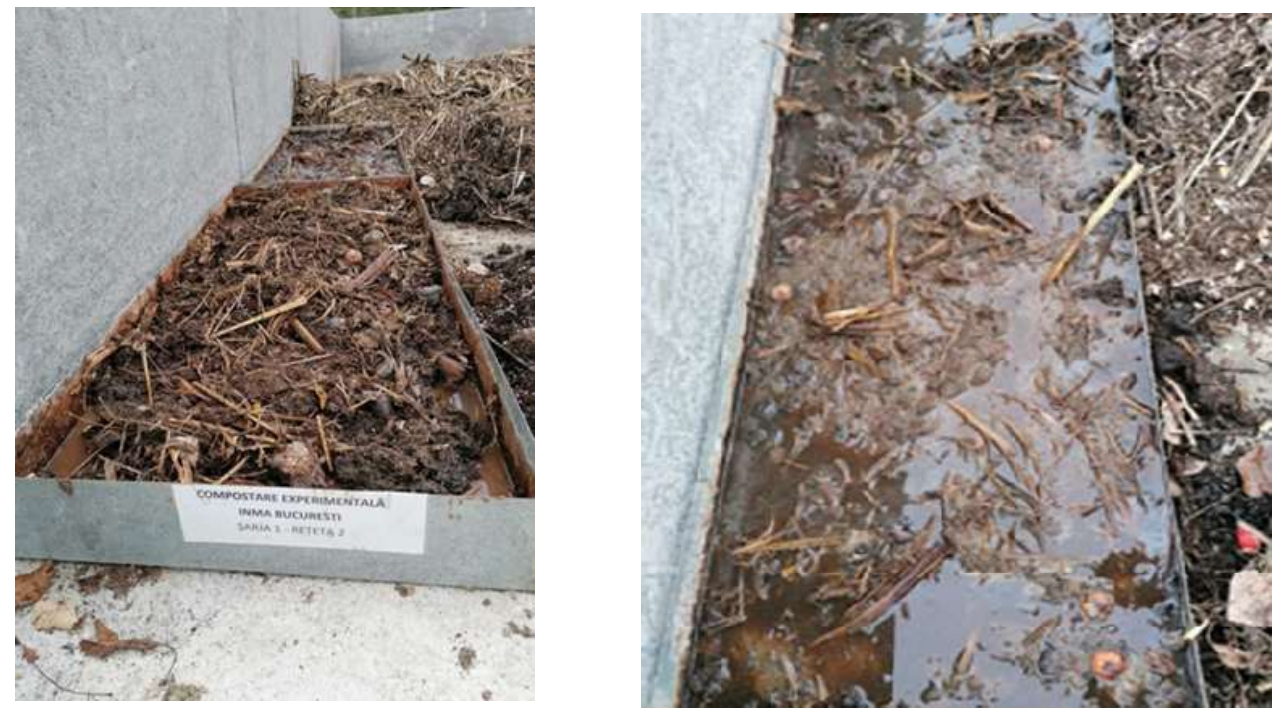

Fig. 4 Images during the experimentation of the recipe for composting 


\section{Results and discussions}

When the temperature is below $40^{\circ} \mathrm{C}$, the composting process it's over.

In table no 2 are listed values of the quality of the resulting compost

Table 2 The quality of the resulting compost

\begin{tabular}{|c|c|c|}
\hline Characteristic & $\mathbf{U} / \mathbf{M}$ & Characteristic value \\
\hline Hygiene & & $\begin{array}{l}\text { A hygienic product that ensures the } \\
\text { exclusion of germs }\end{array}$ \\
\hline Impurities & \multirow[t]{5}{*}{$\%$} & $\begin{array}{l}\text { Impurities greater than } 2 \mathrm{~mm} \text { is not } \\
\text { more than } 0,6 \%\end{array}$ \\
\hline Glass, plastic, metal & & 0,73 \\
\hline Vegetable residues $(2 \mathrm{~mm})$ & & 0,6 \\
\hline Stones & & 0,5 \\
\hline $\begin{array}{l}\text { Type of compost and } \\
\text { material introduced in the } \\
\text { pile }\end{array}$ & & $\begin{array}{l}\text { Green plant residues (plant } \\
\text { removed from the vegetable crops) } \\
\text { Chopped apples } \\
\text { Chopped vegetables (waste } \\
\text { tomatoes and peppers) } \\
\text { Waste from a poultry farm } \\
\text { Deciduous leaves and vegetable } \\
\text { scraps from harvesting onions that } \\
\text { limit dehydration }\end{array}$ \\
\hline $\begin{array}{l}\text { The compost maximum } \\
\text { particle size }\end{array}$ & $\mathrm{mm}$ & 15 \\
\hline Material density & $\mathrm{Kg} / \mathrm{m}^{3}$ & 410 \\
\hline Salt content & & 0,09 \\
\hline $\mathrm{pH}$ value & & 9 \\
\hline The decomposition degree & & $\begin{array}{l}\text { Mature compost: phase IV (degree } \\
\text { of rot) }\end{array}$ \\
\hline The compost water content & $\%$ & $43 \%$ \\
\hline Zinc $(\mathrm{Zn})$ & & $400 \mathrm{mg} / \mathrm{kg} \mathrm{DS}$ \\
\hline Lead $(\mathrm{Pb})$ & & $150 \mathrm{mg} / \mathrm{kg} \mathrm{DS}$ \\
\hline Copper $(\mathrm{Cu})$ & & $100 \mathrm{mg} / \mathrm{kg} \mathrm{DS}$ \\
\hline Chrome $(\mathrm{Cr})$ & & $100 \mathrm{mg} / \mathrm{kg} \mathrm{DS}$ \\
\hline Nickel (Ni) & & $50 \mathrm{mg} / \mathrm{kg}$ DS \\
\hline Cadmium $(\mathrm{Cd})$ & & $1,5 \mathrm{mg} / \mathrm{kg} \mathrm{DS}$ \\
\hline Mercury (Hg) & & $1,0 \mathrm{mg} / \mathrm{kg} \mathrm{DS}$ \\
\hline
\end{tabular}

\section{Conclusions}

So, in conclusion we can say that the temperature is the most important value that must be monitored during the process of transformation into compost, because it can be very easily be measured and shows the progress of the process. The decomposition of organic substances as a result of the activity of microorganisms due to their self-heating capacity is the reason for the temperature differences in the center of the pile and the surrounding temperature. Compost is the result of microbial decomposition of dead matter by oxygen. 
With the use of compost, there is a wide range of benefits. Factors, such as the input material or raw material, the method of composting, storage and application of compost, all these things have an influence on the characteristics of the compost.

\section{References}

1. Caba I.L PN 1910 02Contract no.: 5N / 7.02.2019 Research regarding the realization of a technology for the production of biohumus (vermicompost) "Prospective studies on innovative technologies for the production of biohumus existing worldwide", (2019)

2. Glenn, M., Manual of On-Farm Vermicomposting and Vermiculture. Organic Agriculture Centre of Canada, (2009).

3. G.E.O.R.G., Feasibility of developing the market of organic and transitional farms for the processing of organic farm waste and municipal waste using large-scale vermicomposting. Ed. Good Land Organic Resources Group , Halifax, Nova Scotia, (htpp://alternativeorganic.com), (2004).

4. Rink, R. (Editor), Farm Composting Guide. Natural Resources, Agriculture and Engineering Service (NRAES-54), (1992).

5. http://asociatiacompostului.ro

6. http://www.ecoteca.ro/compostarea-deseurilor-aspecte-esentiale.html 